\title{
SISTEM INFORMASI GEOGRAFIS PENENTUAN LAYANANAN PERIJINAN PENGAMBILAN AIR TANAH DI WILAYAH 1 CIANJUR
}

\author{
Ai Musrifah ${ }^{1}$, Irpan Maulana ${ }^{2}$ \\ Program Studi Teknik Informatika \\ Universitas Suryakancana \\ aimusrifah@unsur.ac.id ${ }^{l}$
}

\begin{abstract}
Increasing the need for ground water resources and making groundwater extraction permits is a challenge that must be faced by the Technical Implementation Unit of the Department of Energy and Mineral Resources (UPTD ESDM) Cianjur Regency which has the main task in managing natural resources including one of mineral resources groundwater. The higher demand for groundwater extraction permits in the ESDM UPTD, it is necessary to have a system capable of providing the right area information for groundwater resource retrieval, managing field review results and displaying information on the well location points, in addition to field staff to fill out the results direct field review of the system making it easier for field officers to conduct field assessments appropriately and quickly. Geographic information system is a system that can be used to process enter, store, manage and retrieve georeferenced data or geospatial data to support decision making in land use planning and management. Geographic Information System Design uses a software engineering model waterfall with UML modeling language (unified modeling language) and tools used to design the usecase diagrams, activity diagrams, class diagrams and Sequence Diagrams and for the representation of maps using Google Maps API. Geographic Information System designed has advantages in facilitating the managing point of area of groundwater resource acquisition as well as data of incoming request making it easier in recording data search and mempmuah in making permit.
\end{abstract}

Keywords: Geographic Information System, Licensing of Ground Water Taking, Waterfall

\begin{abstract}
Abstrak
Meningkatnya kebutuhan akan sumber daya air tanah maupun pembuatan perijinan pengambilan air tanah merupakan tantangan yang harus di hadapi oleh Unit Pelaksana Teknis Dinas Energi dan Sumber Daya Mineral (UPTD ESDM) Kabupaten Cianjur yang mempunyai tugas pokok dalam mengelola sumber daya alam termasuk salah satunya sumber daya mineral air tanah. Semakin tingginya permintaan terhadap perijinan pengambilan air tanah di UPTD ESDM, maka perlu ada sebuah sistem yang mampu memberikan informasi wilayah yang tepat untuk pengambilan sumber daya air tanah, mengelola hasil peninjauan lapangan dan menampilkan informasi mengenai
\end{abstract}


titik lokasi sumur, selain itu petugas lapangan dapat mengisi hasil peninjauan lapangan langsung pada sistem sehingga mempermudah petugas lapangan dalam melakukan peninjauan lapangan dengan tepat dan cepat. Sistem informasi geografis merupakan sebuah sistem yang dapat digunakan untuk proses memasukan, menyimpan, mengelola, dan mengambil kembali data yang bereferensi geografis atau data geospatial untuk mendukung pengambilan keputusan dalam perencanaan dan pengelolaan penggunaan lahan. Perancangan Sistem Informasi Geografis ini menggunakan rekayasa perangkat lunak model waterfall dengan bahasa permodelan UML (unified modeling language) serta alat yang digunakan untuk merancang yaitu usecase diagram, activity diagram, class diagram dan Sequence Diagram dan untuk representasi maps menggunakan Google Maps API. Sistem Informasi Geografis yang dirancang mempunyai kelebihan dalam mempermudah mengelola titik wilayah pengambilan sumber daya air tanah serta data permohonan yang masuk sehingga memudahkan dalam pencatatan pencarian data serta mempermuah dalam pembuatan surat ijin.

Kata Kunci : Perijinan Pengambilan Air Tanah, Sistem Informasi Geografis, Waterfall

\section{Pendahuluan}

\subsection{Latar Belakang}

UPTD Energi dan Sumber Daya Mineral Wilayah I Cianjur memiliki tugas pokok untuk mengkoordinasikan, membina dan mengendalikan pelaksanaan kegiatan, salah satunya yaitu menyelenggarakan pelayanan terhadap pelaksanaan pengelolaan data dan informasi bagi masyarakat yang akan mengajukan perijinan pengambilan air tanah.

Proses dalam pembuatan perijinan pengambilan air tanah harus terlebih dahulu dilakukan peninjauan lapangan untuk memastikan wilayah yang tepat dengan melihat kondisi lokasi langsung dan mencatat hasil survai tersebut dalam sebuah laporan hasil peninjauan lapangan tanpa memperhatikan wilayah yang tepat sehingga membutuhkan waktu yang cukup lama, selain itu data hasil peninjauan lapangan masih dalam laporan hasil tulisan sehingga rentan akan kehilangan data. Jika semakin tingginya permintaan perijinan pengambilan air tanah di UPTD ESDM. Melihat dari proses bisnis yang sedang berjalan pada saat ini, maka UPTD ESDM membutuhkan pengelolaan sistem yang mampu mengetahui informasi wilayah yang tepat untuk pengambilan sumber daya air tanah, mengelola hasil peninjauan lapangan dan menampilkan informasi mengenai titik lokasi sumur, selain itu petugas lapangan dapat mengisi hasil peninjauan lapangan langsung pada sistem sehingga mempermudah petugas lapangan dalam melakukan peninjauan lapangan dengan tepat dan cepat.

Sistem informasi geografis (SIG) merupakan bagian dari sistem informasi yang digunakan untuk memasukan, menyimpan, mengelola, dan mengambil kembali data yang bereferensi geografis atau data geospatial untuk mendukung pengambilan keputusan dalam perencanaan dan pengelolaan penggunaan lahan, sumberdaya alam dan pelayanan umum lainnya (Murai 2005). Sistem informasi geografis yang mampu membantu mengetahui informasi wilayah yang tepat untuk pengambilan sumber daya air tanah, mengelola 
hasil peninjauan lapangan dan menampilkan informasi mengenai titik lokasi sumur. Selain itu sistem yang akan digunakan merupakan informasi bereferensi geografis sehingga akan mempermudah dalam pengelolaan basis data tersebut. Sistem informasi geografis tersebut akan dibangun menggunakan PHP dan MySQLuntuk media pengelolaan serta penyimpanan basis datanya dan menggunakan aplikasi google maps untuk menampilkan data yang bereferensi geografis.

\subsection{Rumusan Masalah}

Berdasarkan latar belakang masalah diatas, maka dapat diambil suatu rumusan masalah yaitu bagaimana membangun aplikasi sistem informasi geografis sumber daya air tanah dengan harapan dapat membantu UPTD ESDM untuk mengetahui informasi wilayah yang tepat dalam pengambilan sumber daya air tanah, mengelola hasil peninjauan lapangan dan menampilkan informasi mengenai titik lokasi sumur dengan cepat dan tepat.

\subsection{Maksud dan Tujuan Penelitian}

Maksud dari penelitian ini adalah membuat suatu aplikasi sistem informasi geografis sumber daya air tanah dengan harapan dapat membantu UPTD ESDM untuk mengetahui informasi wilayah yang tepat dalam pengambilan sumber daya air tanah,mengelola hasil peninjauan lapangan dan menampilkan informasi mengenai titik lokasi sumur dengan cepat dan tepat.

Adapun tujuan yang diinginkan adalah:

a. Membuat pengelolaan hasil peninjauan lapangan yang cepat dan tepat.

b. Membantu UPTD ESDM dalam menampilkan data lokasi titik sumur dalam bentuk peta geografis. c. Memberikan informasi wilayah yang tepat untuk pengambilan air tanah.

d. Mempercepat proses pembuatan perijinan pengambilan air tanah.

\subsection{Batasan Masalah}

Agar pembahasan masalah dalam membangun sistem informasi geografis sumber daya air tanah ini tidak terlalu luas maka batasan masalah yang akan dibahas adalah sebagai berikut :

1. Mengelola data permohonan hingga hasil perijinan.

2. Apliklasi berbasis web

3. Pemetaan sistem geografis menggunakan google maps dengan menentukan lokasi titik sumur dan wilayah yang digunakan untuk pengambilan air tanah.

\subsection{Metode Penelitian}

Dalam membangun sistem informasi geografis peninjauan air tanah di Unit Pelaksana Dinas Energi dan SumberDaya Mineral wilayah 1 Cianjur ini menggunakan beberapa metode penelitian sebagai berikut:

A. Survey

Metode ini digunakan untuk mengetahui dan mempelajari kebutuhan aplikasi yang akan dibangun, dimana sumber tersebut di dapatkan berdasarkan hasil peninjauan lapangan sebagai syarat perijinan pengambilan air.

\section{B. Analisis}

Untuk mencapai kebutuhan pengguna, maka dilakukan analisis mengenai penelitian, sehingga di harapkan produk yang nantinya di hasilkan dapat sesuai dengan kebutuhan pengguna.

C. Tinjauan Pustaka 
Dalam perancangan menyertakan daftar pustaka sebagai sumber acuan lain yang mendasari atau menjadi bahan pertimbangan dalam penyusunan penulisan. Sejumlah buku acuan atau referensi yang menjadi bahan utama dapat berupa suatu hasil pemikiran, tulisan ilmiah seperti jurnal maupun non ilmiah yang didapatkan berdasarkan pencarian dari internet dan buku-buku panduan.

D. Metode Rekayasa Perangkat Lunak

Metode rekayasa perangkat lunak yang digunakan adalah metode waterfall. Menurut Pressman metode waterfall adalah model klasik yang bersifat sistematis, berurutan dalam membangun software. Berikut adalah gambaran bagaimana pembuatan sebuah software dari sebuah waterfall model.(Pressman, 2010).

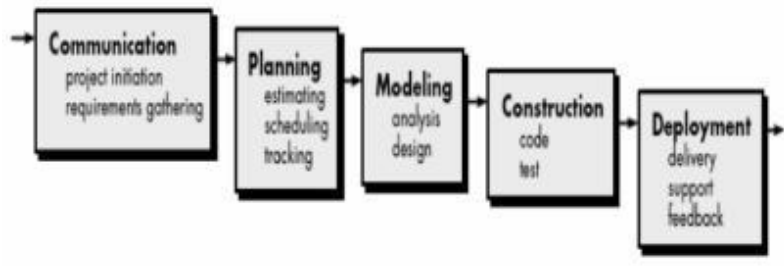

Gambar 1.1 Waterfall Model.(Pressman, 2010)

Tahapan-tahapan dalam metode waterfall menurut

Pressman :

\section{Communication}

Langkah ini adalah analisis terhadap sistem yang sedang berjalan, sehingga dapat mengindentifikasikan terhadap kebutuhan rancangan sistem informasi geografis sumber daya air tanah, dan tahap untuk pengumpulan data dengan melakukan pertemuan dengan pihak UPTD ESDM sebagai pihak yang membutuhkan sistem.

\section{Planning}

Proses Planning ini merupakan proses lanjutan dari proses Communication (Analysis Requirement). Tahapan ini akan menghasilkan User Requirement atau bisa dikatakan sebagai data yang berhubungan dengan keinginan user yaitu UPTD ESDM dalam pembuatan aplikasi sistem informasi geografis sumber daya air tanah, termasuk rencana yang akan dilakukan.

\section{Modeling}

Proses Modeling ini akan menerjemahkan syarat kebutuhan ke sebuah perancangan software yang dapat diperkirakan sebelum dibuat Coding. Proses ini terfokus pada rancangan struktur data $U M L$, arsitektur software, refresentasi interface, dan detail (Algoritma) prosedural, tahapan ini akan menghasilkan rancangan model software requrement.

\section{Construction}

Proses Construction merupakan sebuah proses membuat kode, Coding atau pengkodean merupakan penerjemahan desain dalam bahasa yang dimengerti oleh komputer. Bahasa pempgraman yang digunakan untuk membangun sistem informasi geografis sumber daya air tanah menggunakan bahasa pemograman PHP dan MySQL sebagai tempat penyimpanan data dan google maps sebagai tampilan informasi geografisnya.

\section{Deployment}

Proses Deployment merupakan sebuah tahapan yang bisa dikatakan final dalam pembuatan sebuah software atau sistem. Setelah melakukan analisis, desain dan pengkodean maka sistem yang sudah jadi akan digunakan oleh user. Kemudian software yang sudah jadi harus dilakukan pemeliharaan secara berkala.

\section{Tinjauan Pustaka}

\subsection{Sistem Informasi Geografis}

Sistem Informasi Geografis (SIG) adalah sebuah rangkaian sistem yang memanfaatkan teknologi digital untuk melakukan analisa spasial. SIG dapat mengkaitakan data atributal dengan data spasial, juga dapat memberikan analisis keruangan terhadap data atribut tersebut. Sistem ini memanfaatkan perangkat 
keras dan lunak dari computer untuk melakukan pengolahan data (Budiyanto Eko, 2004)

SIG dapat diuraikan menjadi beberapa subsistem sebagai berikut:

1. Data input, bertugas mengumpulkan dan mempersiapkan data spasial serta atribut dari berbagai sumber. Subsistem ini bertanggungjawab dalam mengkonversi atau mentransformasikan format data asli ke dapat format yang dapat digunakan oleh SIG.

2. Data output, bertugas menampilkan atau menghasilkan keluaran seluruh atau sebagian basis data baik dalam bentuk softcopy maupun hardcopy seperti tabel, peta, dan lain-lain.

3. Data managemen, bertugas mengorganisasikan baik data spasial maupun atribut ke dalam sebuah basis data sehingga mudah dipanggil, diupdate, dan diedit.

4. Data manipulation \& analysis, subsistem ini menentukan informasi yang dapat dihasilkan oleh SIG serta melakukan manipulasi dan pemodelan data untuk menghasilkan informasi yang diharapkan.

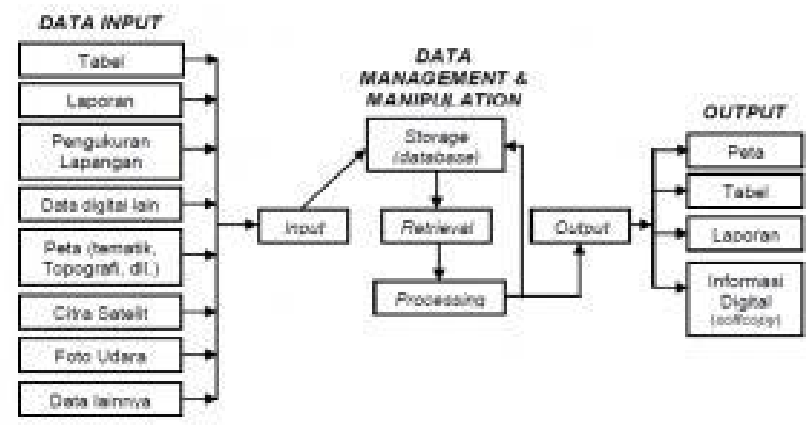

Gambar 2.1 Uraian subsistem-subsistem GIS Komponen-komponen SIG.
1. Hardware, membutuhkan komputer untuk penyimpanan dan pemrosesan data. Ukuran sistem komputer bergantung pada besar kecilnya tipe GIS.

2. Software, harus menyediakan fungsi dan tool yang mampu melakukan penyimpanan data, analisis, dan menampilkan informasi geografis. Elemen yang harus ada pada komponen GIS, yaitu tool (input dan transformasi data geografis); tool yang mendukung query geografis, analisis, dan visualisasi; serta Graphical User Interface (memudahkan akses pada tool geografi).

3. Data, dalam GIS dibagi dua bentuk yaitu geographical (data spasial) dan atribut (data non spasial.

4. Metode, GIS didesain dan dikembangkan untuk managemen data aid yang mendukung pengambilan keputusan organisasi. Pada beberapa organisasi penggunaan GIS dapat dalam bentuk standar tersendiri metode analisisnya, jadi metodologi yang digunakan adalah faktor penentu keberhasilan proyek GIS.

5. Manusia, pengguna GIS memiliki tingkatan tertentu dari tingkatan spesialis teknis mendesain dan memelihara sistem hingga pengguna yang menggunakan GIS untuk menolong pekerjaan mereka sehari-hari.

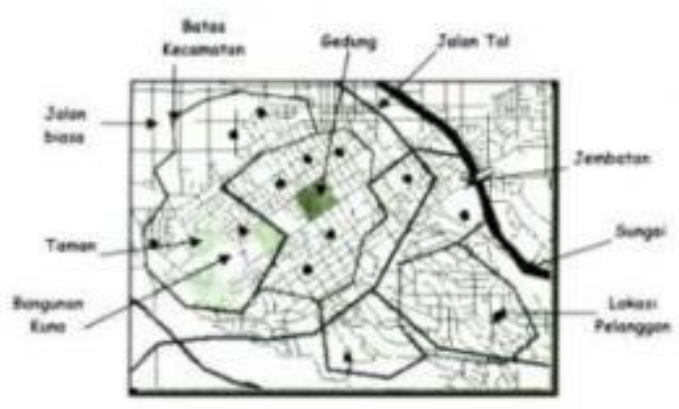

Gambar 2.2 Contoh peta \& unsur-unsurnya 


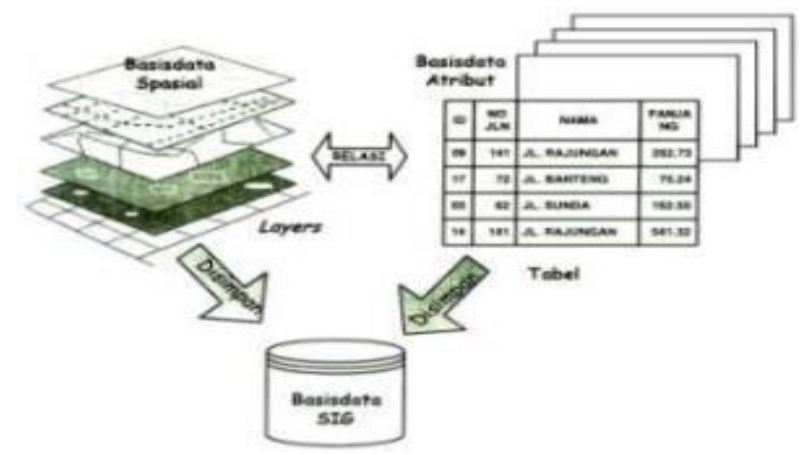

Gambar 2.3 Layers, tabel, dan basis data SIG

Google Maps (GM) merupakan sebuah aplikasi pemetaan online yang cukup popular. Pada GM, titik koordianat suatu tempat ditunjukan dengan sistem koordinat geografis. Lintang dan bujur yang ditampilakan pada GM merupakan dasar dari sistem koordinat geografis digunakan untuk menunjukan suatu titik bumi. Garis lintang yaitu garis vertikal yang mengukur sudut antara suatu titik dengan garis Katulistiwa. Garis bujur yaitu garis horizontal yang mengkukur sudut antara suatu titik nol di bumi, yaitu Greenwich di London, Britania Raya yang merupakan titik bujur $0^{\circ}$ atau $360^{\circ}$ yang diterima secara internasional. Untuk pengguna akhir dalam hal integrasi data spasial dan data non spasial menggunakan MySQL yang merupakan perangkat lunak yang mengatur database yang berhubungan (Relational Database Management System atau RDBMS) (Sirenden. Dkk, 2012).

\section{Analisis dan Perancangan Sistem}

\subsection{Analisis Sistem yang Sedang Berjalan}

Sistem yang sedang berjalan di Unit Pelaksana Teknis Dinas Energi dan Sumber Daya Mineral Wilayah 1 Cianjur pengenai pengelolaan sumber daya air tanah masih belum sepenuhnya terkomputerisasi. UPTD ESDM Wilayah I Cianjur mempunyai tugas pokok melaksanakan sebagian fungsi Dinas di bidang pelayanan, konservasi dan pelestarian serta kegiatan teknis operasional, sebagian urusan bidang energi dan sumber daya mineral, salah satunya adalah sumber daya air tanah yang memiliki perijinan dalam proses pengambilannya.

Proses perijinan pengambilan air tanah di mulai dari pengajuan kepada pihak BPMPT yang akan diberikan tugas peninjauan lapangan kepada UPTD ESDM daerah masing-masing wilayahnya.

Setelah didapatkan data pemohon maka dilakukan peninjauan lapangan oleh petugas lapangan dari UPTD ESDM yang akan melaporkan hasil peninjauan lapangan kepada Dinas ESDM berupa laporan tulis manual serta sampel air ke balai pengujian untuk dilakukan uji sampel.

Balai uji sampel akan melakukan uji pada sampel air yang nantinya data sampel air akan di kelola di UPTD ESDM sebagai data pendukung untuk pengambilan sumber daya air tanah dengan melihat kandungan yang terdapat pada air yang telah di lakukan uji sampel. Selanjutnya UPTD ESDM akan mengelola data hasil peninjauan lapangan yang akan di serahkan kepada Dinas ESDM pusat untuk dilakukan pertimbangan.

\subsection{Analisis Masalah}

Beberapa persoalan yang terjadi di Unit Pelaksana Dinas Energidan Sumber Daya Mineral Wilayah 1 Cianjur adalah sebagai berikut :

1. Belum adanya sistem informasi pengelolaan permohonan.

2. Belum ada sistem yang mampu memberikan informasi wilayah yang tepat untuk pengambilan air tanah

3. Belum ada sistem informasi geografis yang mampu menampilkan titik wilayah pengambilan air tanah.

4. Dengan adanya sistem yang ada sekarang dinilai masih kurang dalam hal pengelolaan sumber daya air tanah, karena dengan jumlah pemohon yang 
Ai Musrifah ${ }^{1}$, Irpan Maulana ${ }^{2}$, Sistem Informasi Geografis Penentuan Layananan Perijinan Pengambilan Air Tanah Di Wilayah 1 Cianjur

semakin meningkat pengelolaan data yang masih manual menyebabkan pengelolaan tidak maksimal.

\subsection{Analisis Kebutuhan Data}

Pengelolaan data hasil peninjauan lapangan yang akan digunakan untuk data pendukung dalam memutuskan perijinan pengambilan air tanah. Data peninjauan lapangan dapat memberikan informasi mengenai wilayah mana saja yang tepat untuk digunakan sebagai tempat pengambilan sumber daya air tanah. Berikut merupakan data parameter pengujian kualitas air yang ter akreditasi berdasarkan PP.RI No.82 Tahun 2001 yang memberikan informasi mengenai pengambilan sumber daya air tanah.

Tabel 3.1 Parameter Pengujian Kualitas Air

\begin{tabular}{|c|c|c|c|c|c|c|c|}
\hline \multirow{2}{*}{$\begin{array}{l}\mathrm{N} \\
\mathrm{o}\end{array}$} & \multirow{2}{*}{$\begin{array}{l}\text { Param } \\
\text { eter }\end{array}$} & \multirow[b]{2}{*}{$\begin{array}{l}\text { Sat } \\
\text { uan }\end{array}$} & \multicolumn{4}{|c|}{ Batas Maksimum } & \multirow[t]{2}{*}{ Stdr } \\
\hline & & & Kls I & $\begin{array}{c}\text { Kls } \\
\text { II }\end{array}$ & $\begin{array}{c}\text { Kls } \\
\text { III }\end{array}$ & $\begin{array}{l}\text { Kls } \\
\text { IV }\end{array}$ & \\
\hline \multicolumn{8}{|c|}{ I. FISIKA } \\
\hline 1 & $\begin{array}{l}\text { Tempe } \\
\text { ratur }\end{array}$ & $\bar{C}$ & \multicolumn{4}{|c|}{ Temperature lingkungan } & 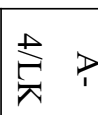 \\
\hline 2 & $\begin{array}{l}\text { Residu } \\
\text { Tersus } \\
\text { pensi } \\
\text { (TSS) }\end{array}$ & $\begin{array}{l}\mathrm{mg} / \\
\mathrm{L}\end{array}$ & 50 & 50 & 400 & $\begin{array}{c}40 \\
0\end{array}$ & \\
\hline 3 & $\begin{array}{l}\text { Residu } \\
\text { Terlar } \\
\text { ut } \\
\text { (TDS) }\end{array}$ & $\begin{array}{l}\mathrm{mg} / \\
\mathrm{L}\end{array}$ & 1000 & $\begin{array}{c}100 \\
0\end{array}$ & 1000 & $\begin{array}{l}20 \\
00\end{array}$ & \\
\hline
\end{tabular}

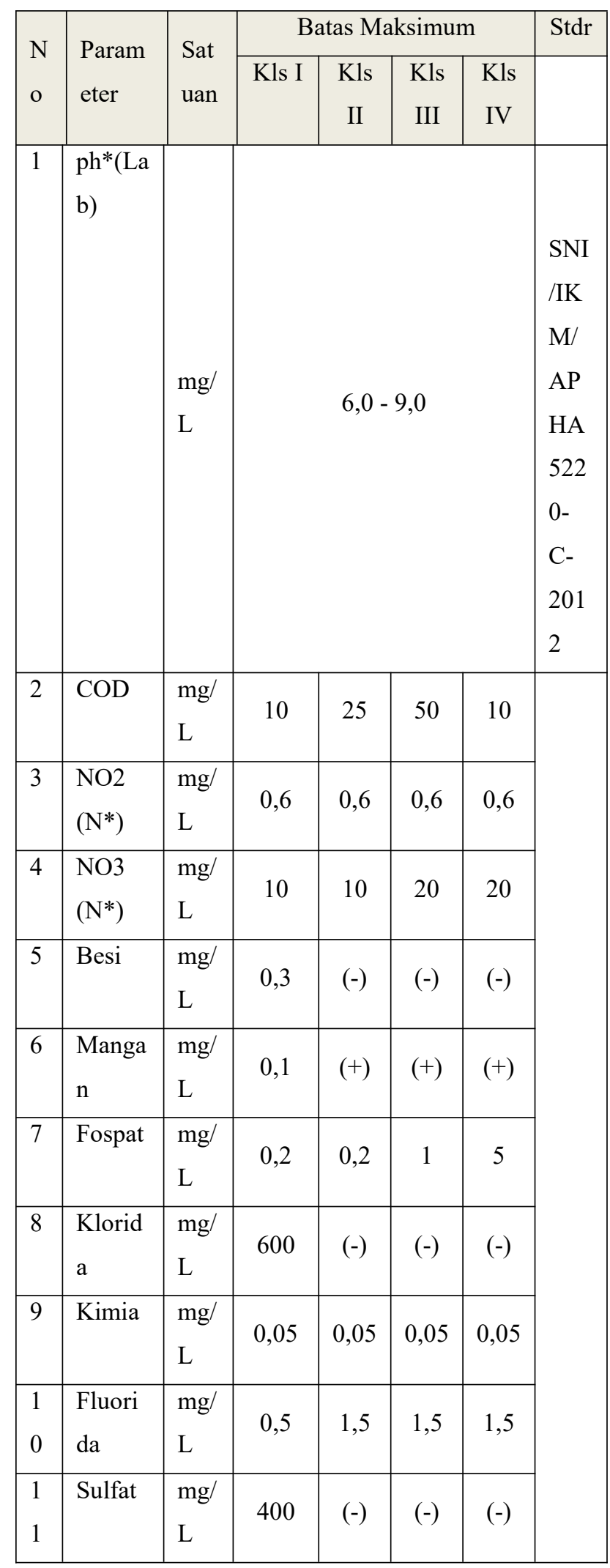


Dengan adanya kandungan dan kelas penggunaan pada sumber daya air sehingga dapat di ketahui beberapa jenis air dan sumur yang ada di Kabupaten Cianjur diantaranya :

Tabel 3.2 Jenis Sumber Daya Air Tanah

\begin{tabular}{|l|l|c}
\hline No & $\begin{array}{c}\text { Nama Jenis Air } \\
\text { Tanah }\end{array}$ & \multicolumn{1}{c}{ Wilayah Penyebaran } \\
\hline 1 & Freatik & Tersebar Di Semua Kecamatc \\
\hline 2 & Asteris & Tersebar Di Semua Kecamatc \\
\hline 3 & Meteorit (Vados) & Tersebar Di Semua Kecamatc \\
\hline 4 & Magma (Juvenil) & Tersebar Di Semua Kecamatc \\
\hline 5 & Kronat & Tersebar Di Semua Kecamatc \\
\hline
\end{tabular}

Tabel 3.3 Jenis Sumur

\begin{tabular}{|l|l|c|}
\hline No & \multicolumn{1}{|c|}{ Jenis Sumur } & Jumlah \\
\hline 1 & Sumur Gali (SG) & $>5000$ Titik \\
\hline 2 & Sumur Bor (SB) & $>5000$ Titik \\
\hline 3 & Sumur Pantek (SP) & $>5000$ Titik \\
\hline 4 & Sumur Mata Air (MA) & $>5000$ Titik \\
\hline 5 & Sumur ASR (ASR) & $>5000$ Titik \\
\hline 6 & Sumur Imbuhan (SI) & $>5000$ Titik \\
\hline 7 & Sumur Pantau Telemetri (SPT) & $>5000$ Titik \\
\hline 8 & Sumur Pantau Dangkal (SPD) & $>5000$ Titik \\
\hline 9 & Sumur Pantau AWLR & $>5000$ Titik \\
\hline 10 & Sumur Pantau Manual (SPM) & $>5000$ Titik \\
\hline 11 & Biopori (BIO) & $>5000$ Titik \\
\hline
\end{tabular}

\subsection{Analisis Kebutuhan Fungsional}

Berikut ini adalah Use Case Diagram yang menggambarkan fungsionalitas yang diharapkan dari sebuah sistemdari sistem informasi geografis sumber daya air tanah unit pelaksana teknis dinas energi dan sumber daya mineral wilayah 1 Cianjur.

\section{Use case}

Dari Gambar 3.4 Use Case Diagram dapat di ketahui ada 18use case yang menyusun sistem dan terdapat tiga halaman utama yang di gunakan untuk admin, UPTD dan BPMPT, tiap use case memiliki fungsinya masing masing. Serta terdapat 3 aktor yang masuk dalam sistem sebagai admin yang mengelola sistem secara penuh, UPTD dan BPMPTsebagai user untuk mengelola sistem.

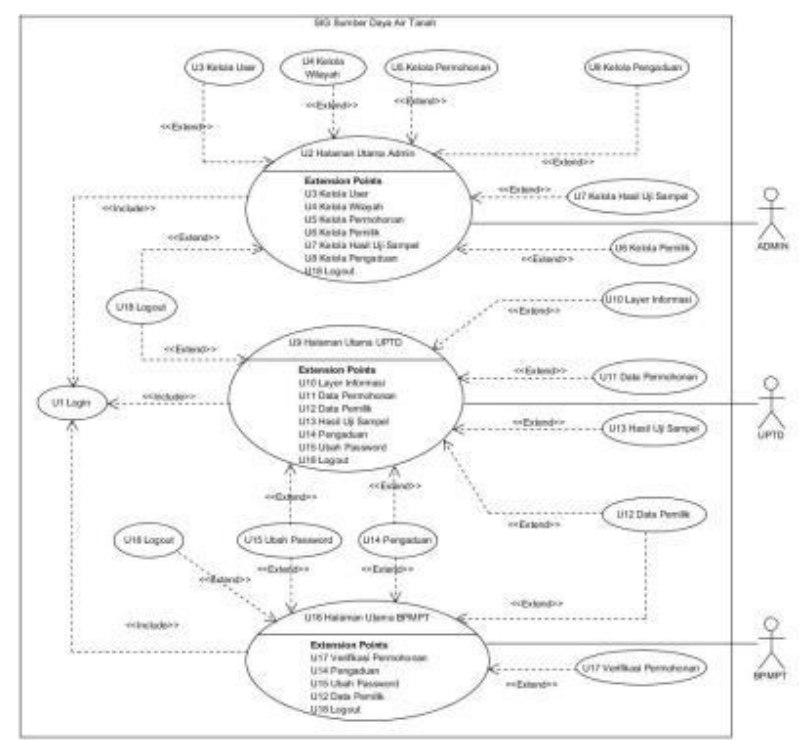

Gambar 3.1 Use Case Diagram

\section{Activity Diagram}

Diagram aktivitas atau activity diagram menggambarkan workflow (aliran kerja) atau aktivitas dari sebuah sistem atau proses bisnis. Activity diagram di gambarkan dengan SwimlaneDiagram. Berikut ini adalah Swimlane Diagram dari Sistem informasi geografis sumber daya air tanah. 


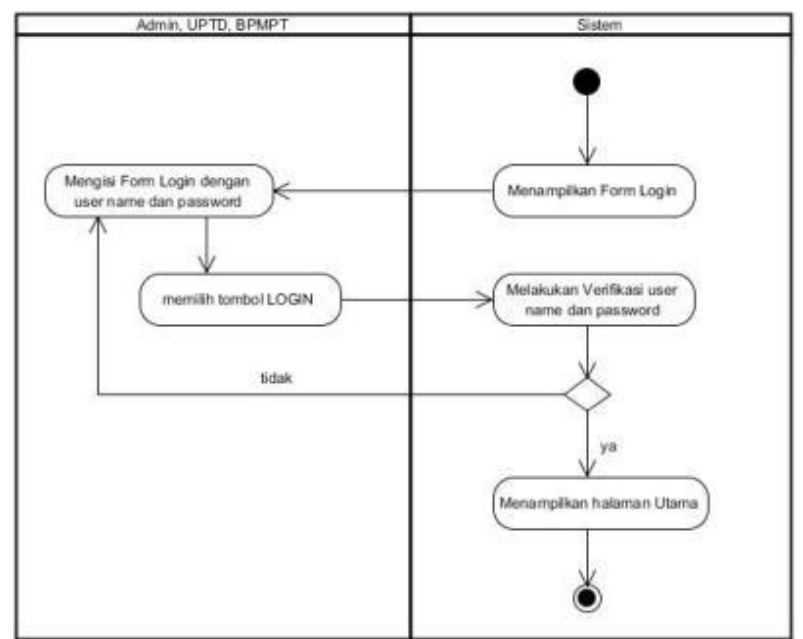

Gambar 3.2 Swimlane Diagram : Login

Berdasarkan gambar 3.3Swimlane Diagram Login terdapat admin,UPTDdan BPMPT yang harus melakukan login ke sistem terlebih dahulu dengan memasukna user name dan password, jika benar akan masuk ke halaman utama masing-masing sistem dan jika salah akan kembali melakukan login.

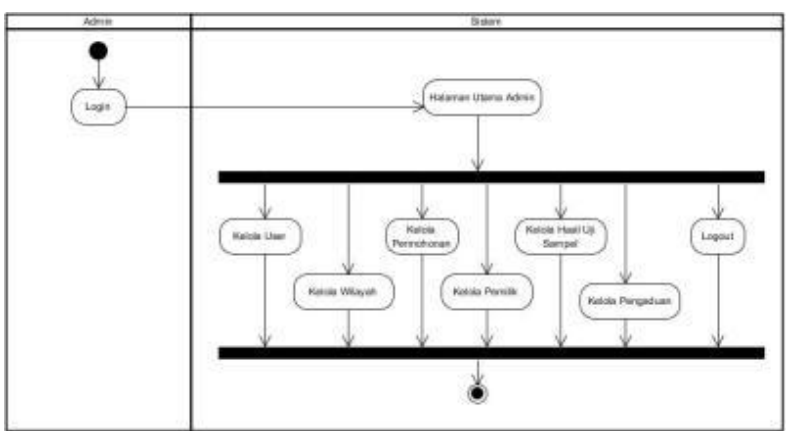

Gambar 3.3 Swimlane Diagram : Halaman Utama Admin

Berdasarkan gambar 3.4Swimlane Diagram Halaman utama admin menampilkan beberapa pilihan menu yang ada pada menu admin setelah berhasil melakukan login beberapa pilihan menu digunakan untuk mengelola sistem, diantaranya kelola user, layer informasi, data wilayah, Map, kelola permohonan, kelola pemilik, hasil uji sampel dan logout untuk keluar dari sistem.

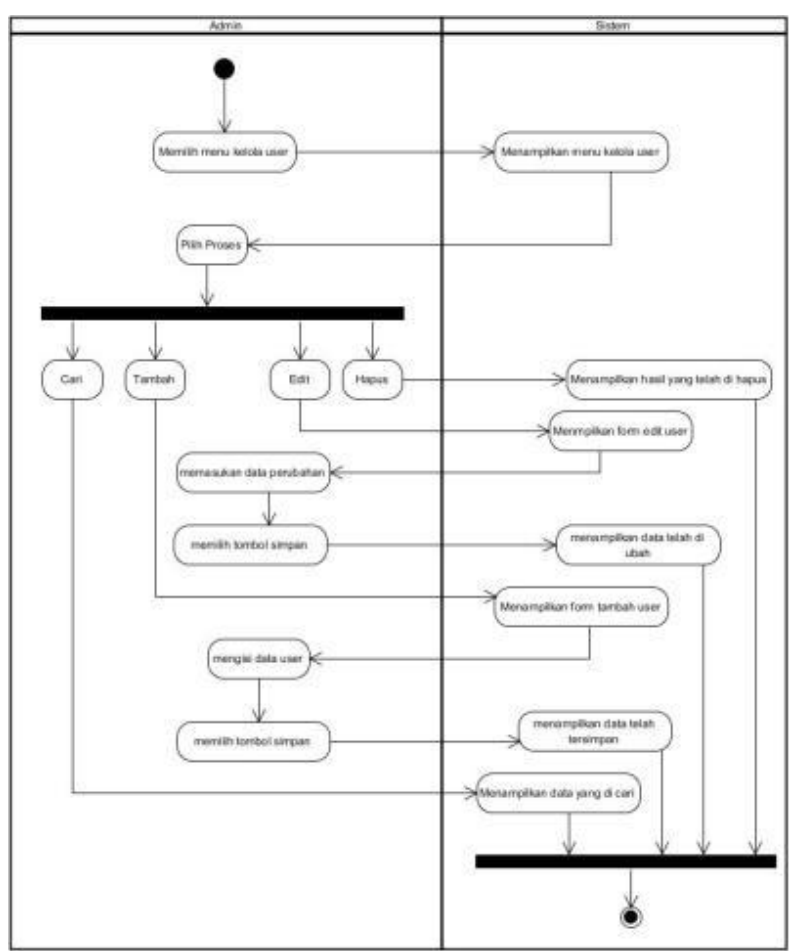

Gambar 3.4 Swimlane Diagram : Kelola User

Berdasarkan gambar 3.5Swimlane Diagram kelola user admin dapat melakukan pengelolaan user yang menggunakan sistem. Admin dapat melakukan tambah, edit, hapus dan cari user pada menu kelola user.

Berdasarkan gambar 3.6 Swimlane Diagram layer informasi di gunakan oleh UPTD untuk melakukan pencarian wilayah dan titik sumur dalam bentuk peta. UPTD dapat mencari wilayah yang di ajukan pemohon yang telah masuk dalam data wilayah.UPTD dapat melakukan penambahan permohonan dari wilayah yang di cari jika wilayah sesuai. 
MJI Vol.10, No.1, Juni 2018, hlm. 39-53

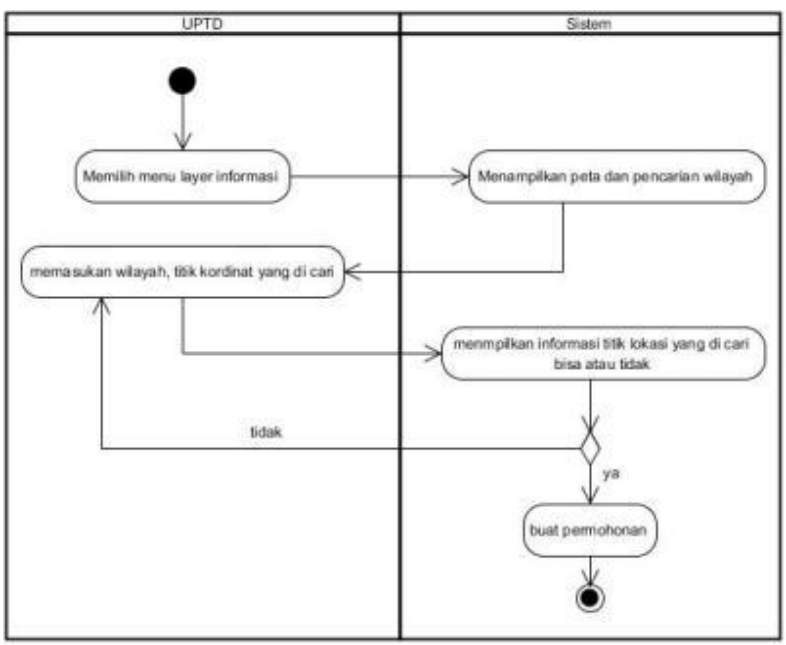

Gambar 3.5 Swimlane Diagram : Layer Informasi

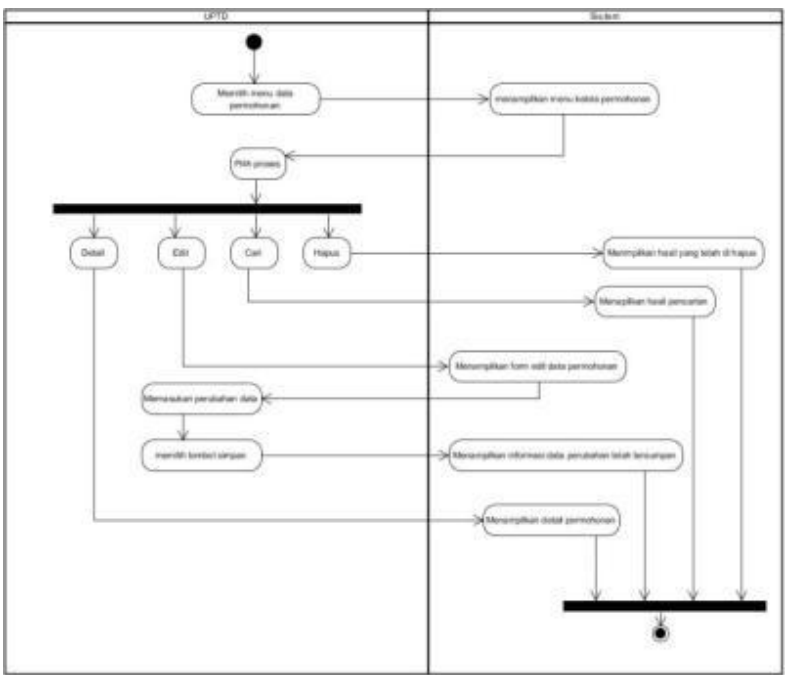

Gambar 3.6 Swimlane Diagram : Data Permohonan

Berdasarkan gambar 3.7 Swimlane Diagram data permohonan di gunakan UPTD untuk melakukan pengelolaan permohonan yang masuk yang selanjutnya akan jadi perijinan pengambilan air.UPTD dapat melakukan ubah, hapus, cari dan lihat detail permohonan.

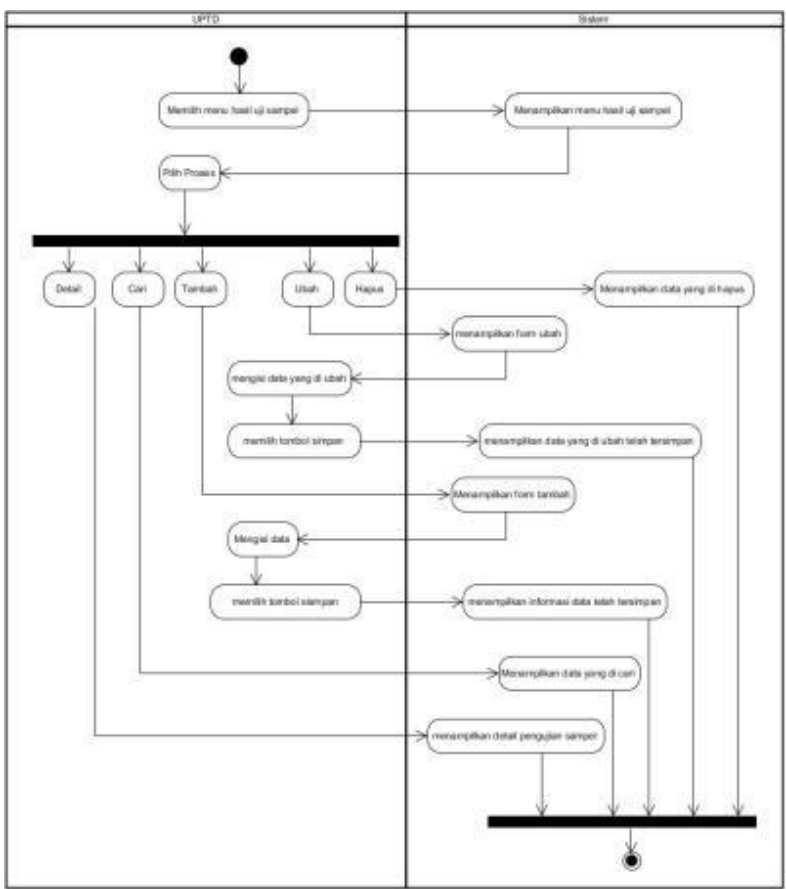

Gambar 3.7 Swimlane Diagram : Hasil Uji Sampel

Berdasarkan gambar 3.8 Swimlane Diagram hasil uji sampel di gunakan oleh UPTD untuk melakukan pengelolaan hasil pengujian sampel air yang di dapat dari tiap wilayah pengambilan dan titik sumur.UPTD dapat melakukan tambah, edit, hapus, cari dan lihat detail hasil uji sampel.

\section{Class Diagram}

Berdasarkan gambar 3.9 Class Diagram Sistem Informasi Geografis Sumber Daya Air Tanah Unit Pelaksana Teknis Dinas Energi Dan Sumber Daya Mineral Wilayah 1 Cianjur class login memiliki hubungan asosiasi dengan class permohonan, pemilik hal ini dikarenakan class - class tersebut memiliki ketergantungan terhadap class login, sedangkan antaraclass map, classsumur, classdata wilayah dan class hasil pengujian sampel memiliki hubungan strongaggregation. 
Ai Musrifah ${ }^{1}$, Irpan Maulana ${ }^{2}$, Sistem Informasi Geografis Penentuan Layananan Perijinan Pengambilan Air Tanah Di Wilayah 1 Cianjur

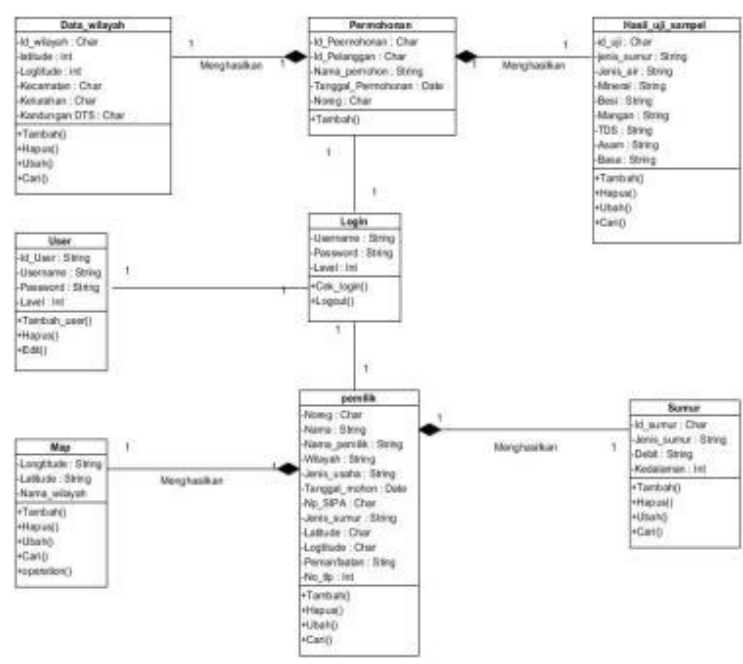

Gambar 3.8 Class Diagram

4. Sequence Diagram

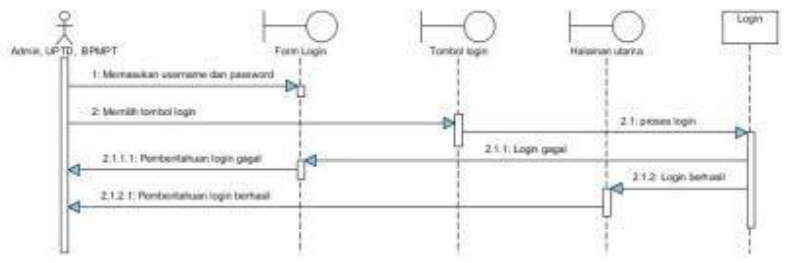

Gambar 3.9 Sequence Diagram login

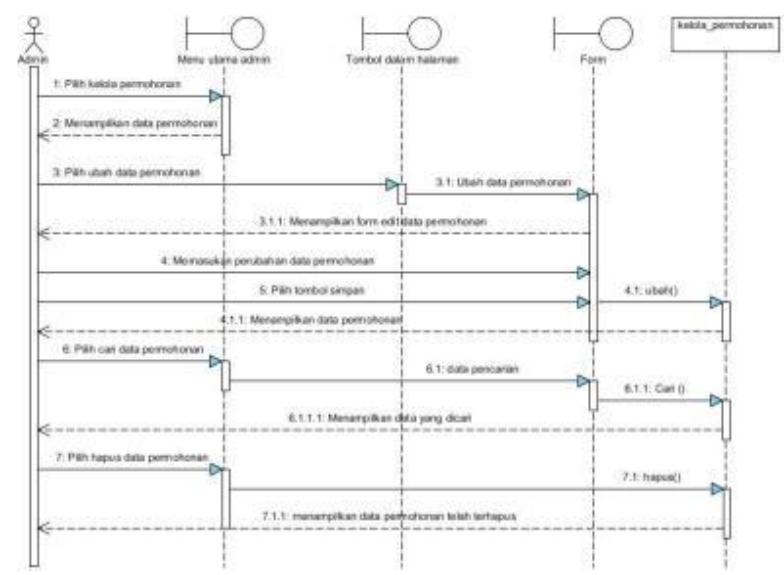

Gambar 3.10 Sequence Diagram Kelola Permohonan

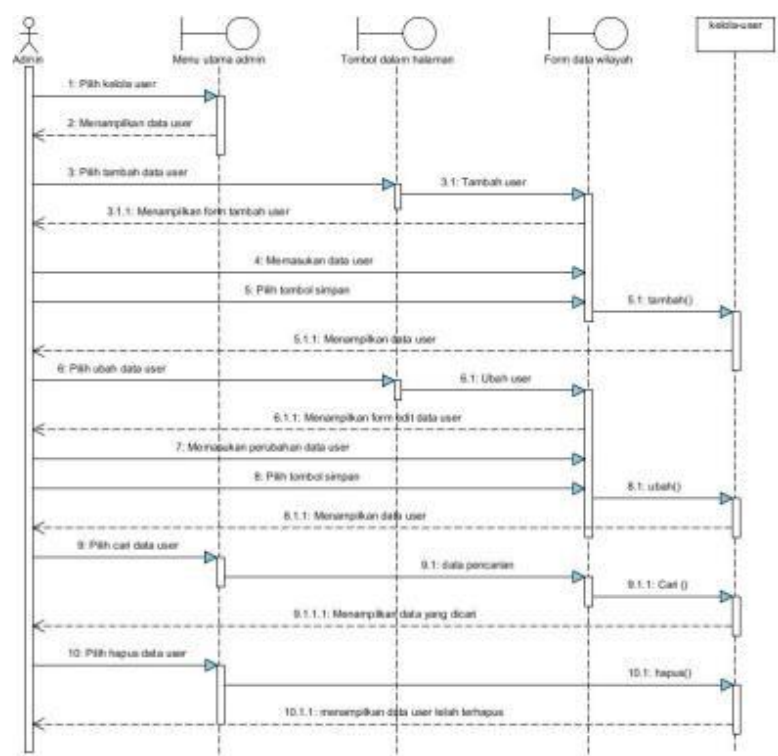

Gambar 3.11 Sequence Diagram Kelola user

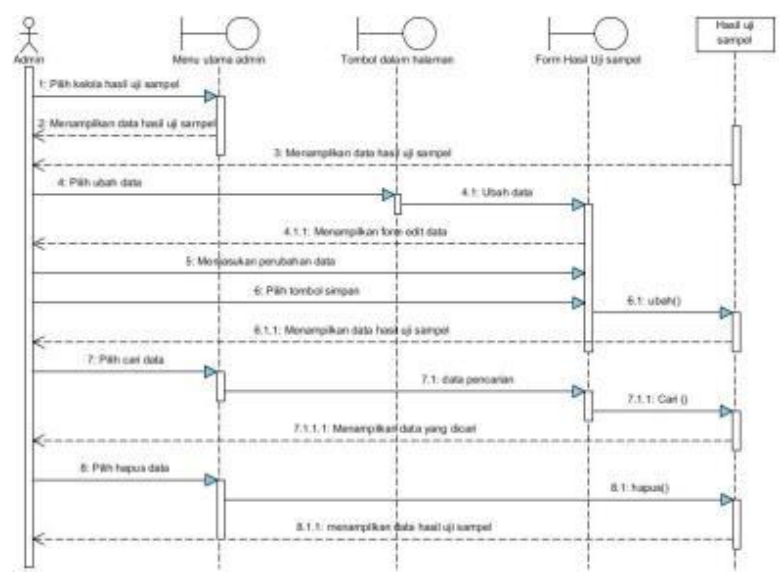

Gambar 3.12 Sequence Diagram Kelola hasil Uji

Sample

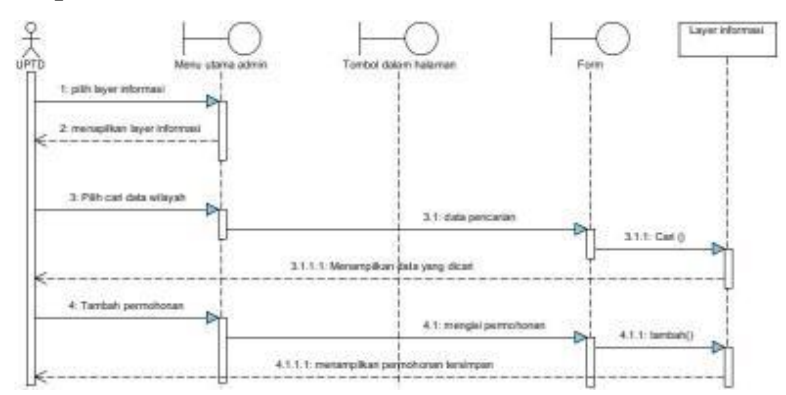

Gambar 3.13 Sequence Diagram Layer Informasi 
MJI Vol.10, No.1, Juni 2018, hlm. 39-53

Entity Relationship Diagram merupakan pemodelan konseptual yang didesain secara khusus untuk mengidentifikasikan entitas yang menjelaskan data dan hubungan antar entitas secara fisik.

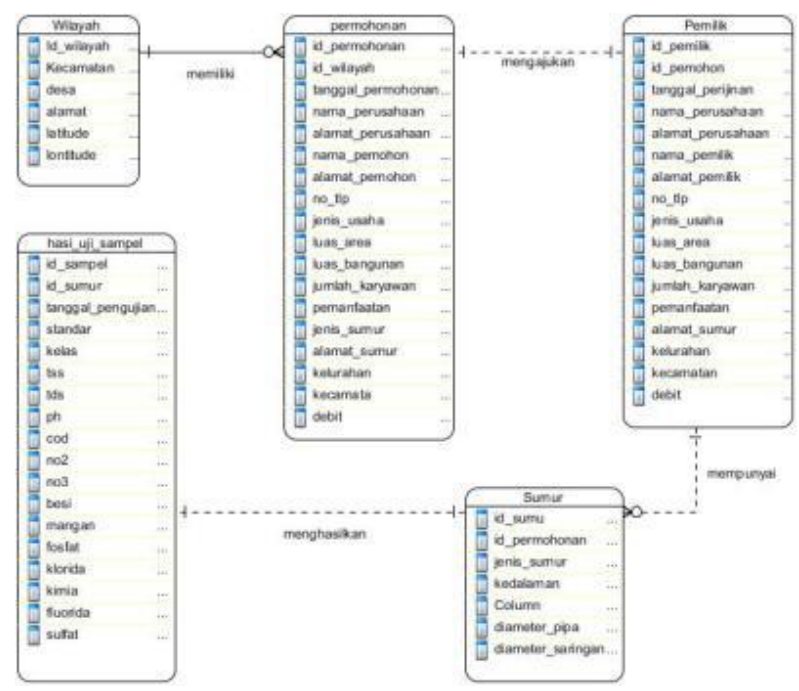

Gambar 3.14 Entity Relationship Diagram

\subsection{Perancangan Sistem}

1. Perancangan Menu

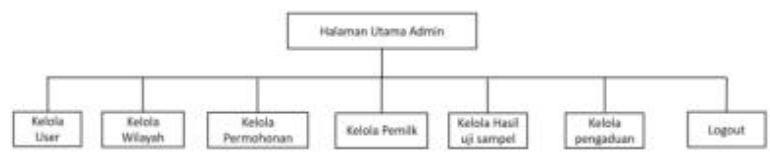

Gambar 3.15 Perancangan menu

2. Perancangan Struktur Navigasi Web

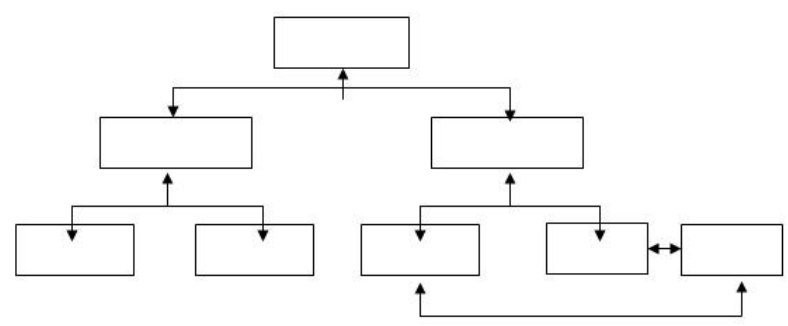

Gambar 3.16 Perancangan Struktur Navigasi Web

\section{Perancangan Antarmuka}

Perancangan antarmuka merupakan rancagan antarmuka aplikasi yang nantinya akan dibangun. Pada tahap analisis, telah dilakukan kajian untuk mengetahui komponen-komponen yang diperlukan pada pembuatan aplikasi Berikut ini adalah perancangan antarmuka pembuatan aplikasi Pengelolaan registrasi surat izin pengusahaan air tanah :

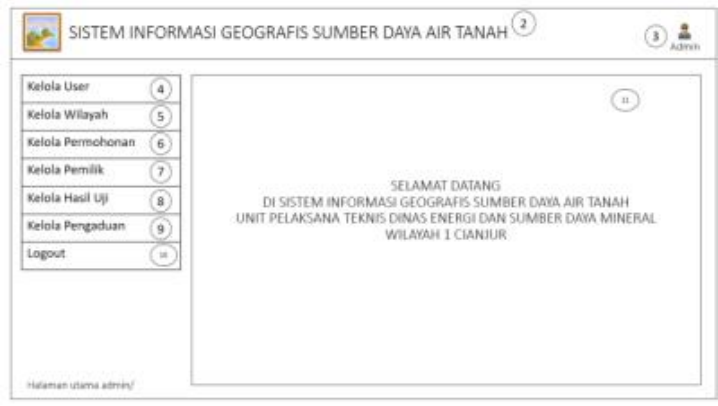

Gambar 3.17 Antarmuka Halaman Utama Admin

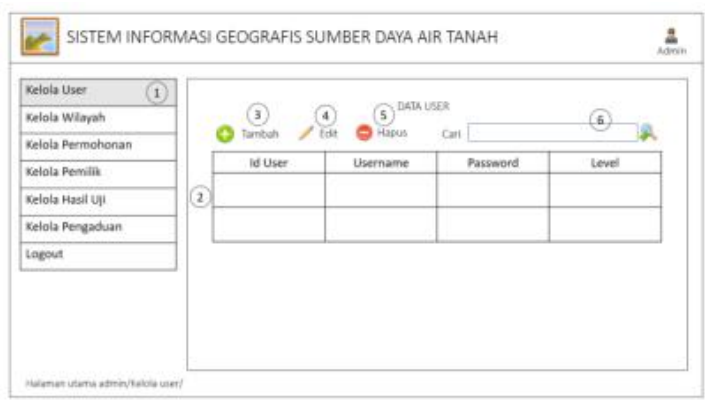

Gambar 3.18 Antarmuka Kelola User

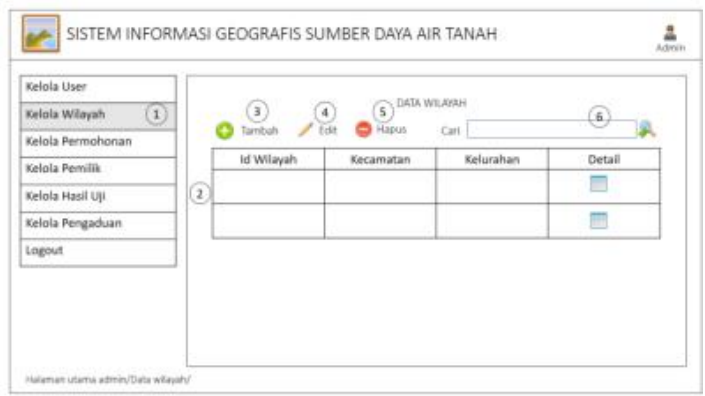

Gambar 3.19 Antarmuka Kelola Wilayah 
Ai Musrifah ${ }^{1}$, Irpan Maulana ${ }^{2}$, Sistem Informasi Geografis Penentuan Layananan Perijinan Pengambilan Air Tanah Di Wilayah 1 Cianjur

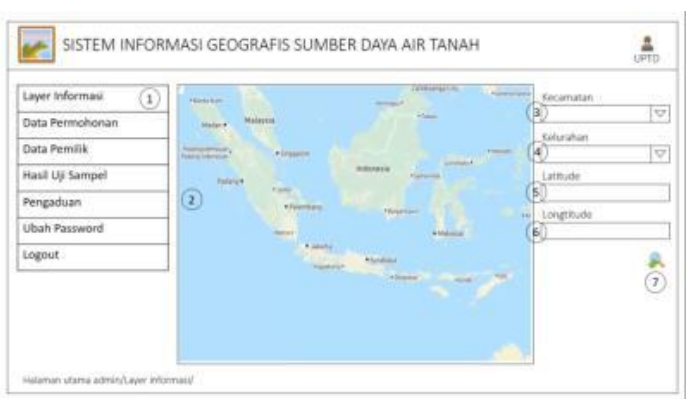

Gambar 3.20 Antarmuka Leyer Informasi

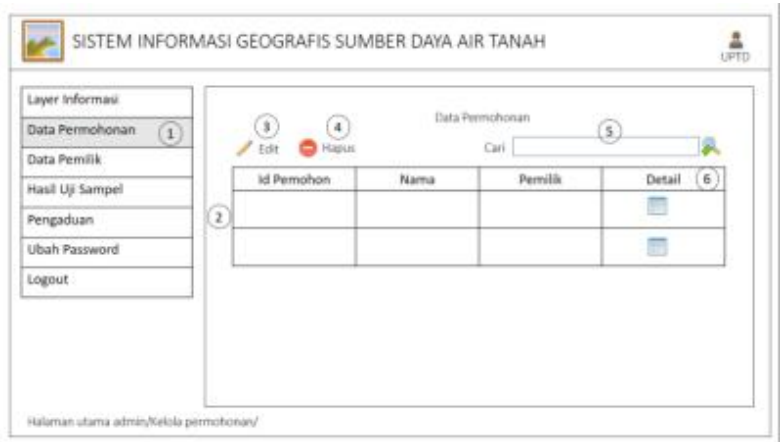

Gambar 3.21 Antarmuka Data Pemohon

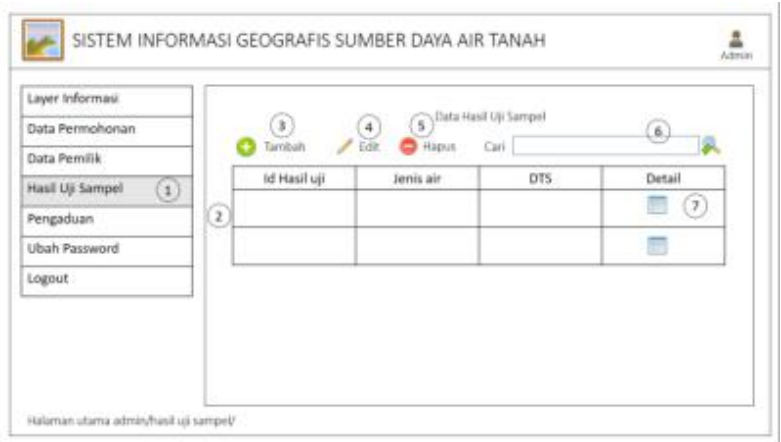

Gambar 3.22 Antarmuka Uji Sample

\section{Hasil}

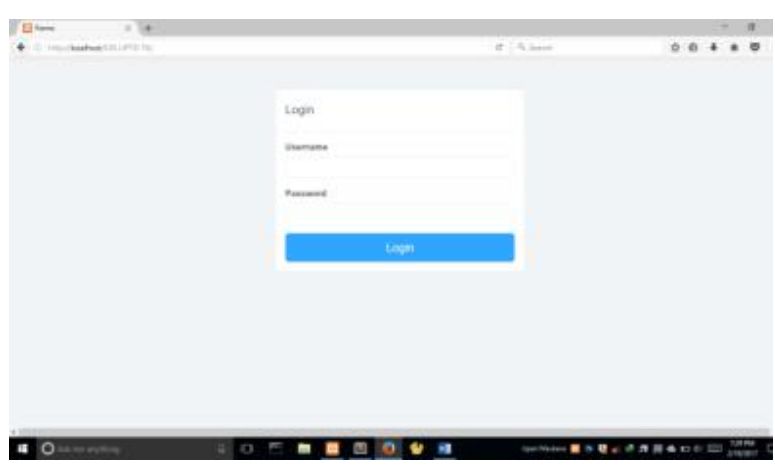

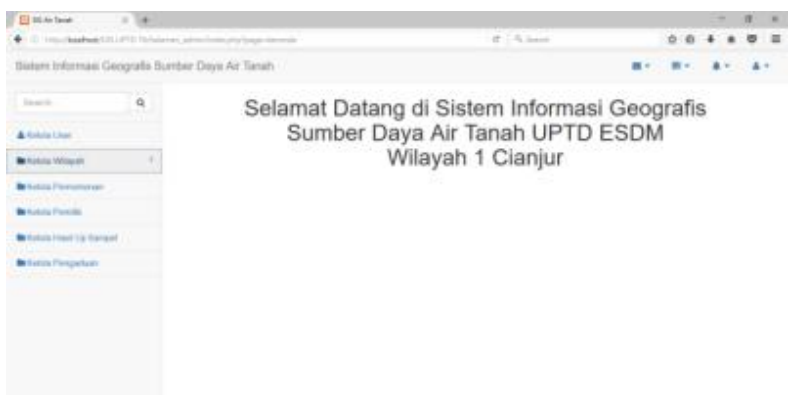

a 0
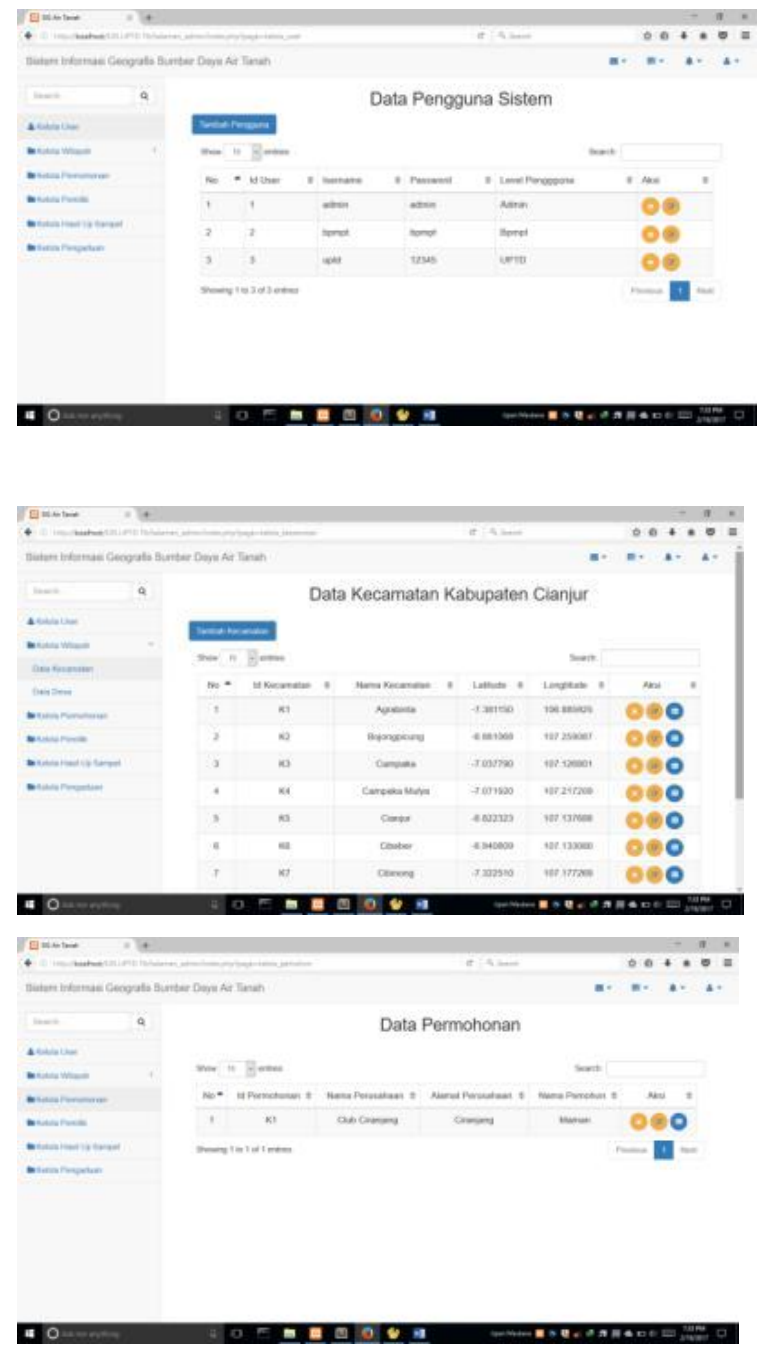

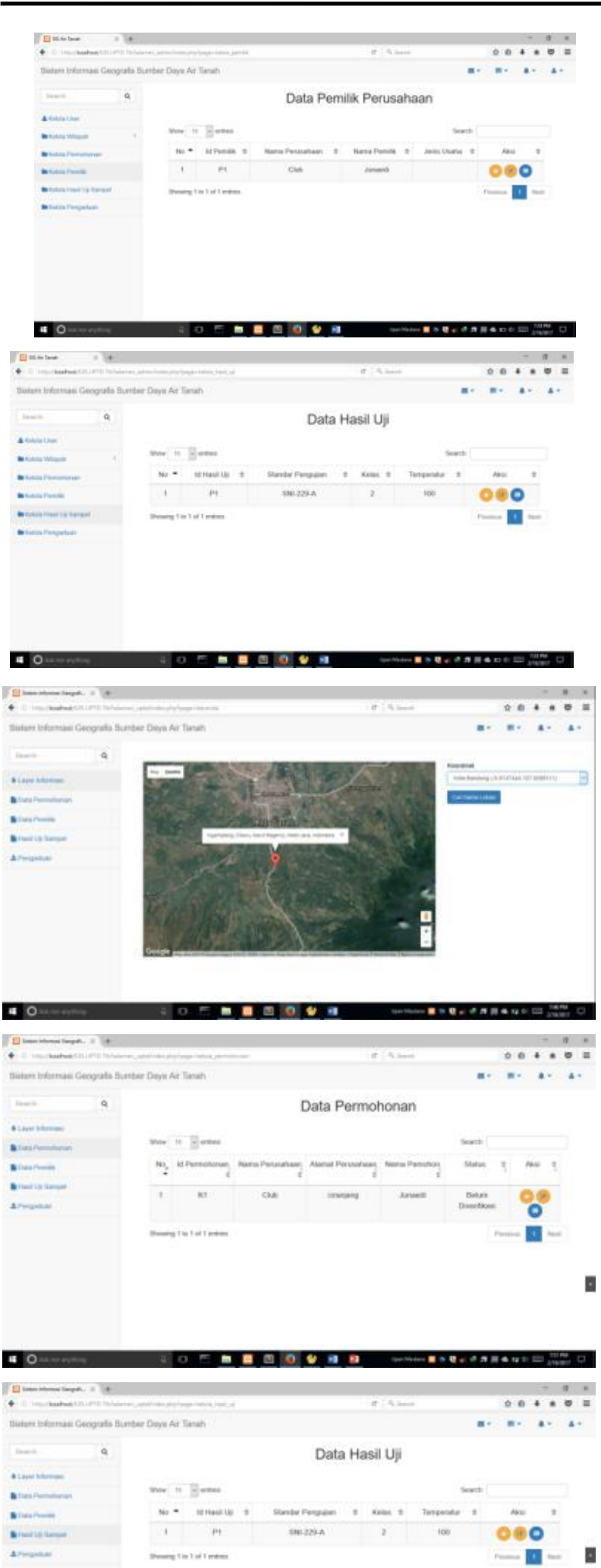

\section{Penutup}

\subsection{Simpulan}

Dari hasil penelitian, perancangan dan implementasi yang telah dilakukan, dapat disimpulkan antara lain :

1. Sistem informasi geografis sumber daya air tanah ini dapat membantu unit pelaksana teknis dinas energi dan sumber daya mineral wilayah 1 Cianjur dalam melakukan pengelolaan sumber daya air tanah dari mulai penentuan lokasi pengambilan, hingga permohonan dan perijinan pengambilan sumber daya air tanah.

2. Mempermudah UPTD ESDM dalam mengetahui wilayah yang tepat untuk pengambilan air tanah dan permohonan perijinan pengambilan air tanah sehingga lebih mudah dalam pencatatan dan pembuatan surat perijinan.

\subsection{Saran}

Beberapa saran yang dapat diajukan terkait dengan sistem pengelolaan registrasi surat izin pengusahaan air tanah:

1. Sistem informasi geografis ini lebih baik dikembangkan dengan sistem informasi dan registrasi online untuk selanjutnya digunakan oleh pemohon sebagai sumber informasi dan pengiriman permohonan secara online.

2. Akan lebih baik jika aplikasi ini dikembangkan untuk semua jenis pengelolaan sumber daya di ESDM. 
Ai Musrifah ${ }^{1}$, Irpan Maulana ${ }^{2}$, Sistem Informasi Geografis Penentuan Layananan Perijinan Pengambilan Air Tanah Di Wilayah 1 Cianjur

\section{Daftar Pustaka}

[1] Budiyanto, Eko. 2004. Sistem Informasi Geografis Menggunakan MapInfo. Penerbit Andi Yogyakarta 2004

[2] Pressman, Roger S. (2010). Rekayasa Perangkat Lunak: Pendekatan Praktisi Edisi 7. Yogyakarta: Andi Yogyakarta)

[3] Murai, 2005 Sistem Informasi Geografis . Bandung, Informatika

[4] Satriawan, Halus. 2015. Teknologi Konservasi Tanah dan Air, Jakarta: Media Komputindo

[5] Sireden, Bernandus. 2012. Membuat Peta Menggunakan Codeigniter dan Google maps API. Jakarta : Andi Yogyakarta.

[6] Sinamarta, J. (2010). Rekayasa Perangkat Lunak. Yogyakarta: Andi. 